\title{
Peningkatan Keterampilan Mahasiswa PGSD FKIP Universitas Sriwijaya dalam Membuat Media Pembelajaran IPS SD Berbasis Edutainment
}

\author{
Bunda Harini ${ }^{1}$, Nuraini Usman ${ }^{2}$ \\ ${ }^{1,2}$ Pendidikan Guru Sekolah Dasar Universitas Sriwijaya \\ 1harini.bunda@unsri.ac.id \\ ${ }^{2}$ nuraini_usman@fkip.unsri.ac.id
}

\begin{abstract}
ABSTRAK
Penelitian ini bertujuan meningkatkan keterampilan mahasiswa PGSD FKIP Univeristas Sriwijaya dalam membuat media pembelajaran IPS SD berbasis edutainment. Metode yang digunakan dalam penelitian ini adalah kualitatif dalam bentuk penelitian tindakan kelas. Subjek penelitian ini adalah seluruh mahasiswa PGSD Angkatan 2016 FKIP Universitas Sriwijaya Kampus Indralaya yang berjumlah 39. Jumlah tersebut terdiri dari 34 Mahasiswi dan 3 Mahasiswa. Teknik pengumpulan data yang digunakan pada penelitian ini adalah observasi. Oleh karena itu, instrument penelitian ini adalah lembar pedoman observasi keterampilan mahasiswa PGSD FKIP Univeristas Sriwijaya dalam membuat media pembelajaran IPS SD berbasis edutainment. Penelitian tindakan ini dilakukan secara bersiklus yang tiap siklusnya terdiri atas empat tahap yaitu perencanaan, pelaksanaan tindakan, observasi, dan refleksi. Siklus dalam penelitian ini terdiri dari dua pertemuan. Berdasarkan data nilai rata-rata keterampilan mahasiswa PGSD FKIP Univeristas Sriwijaya dalam membuat media pembelajaran IPS SD berbasis edutainment, diketahui bahwa terjadi peningkatan dari 73.72 pada siklus I menjadi 88.97 pada siklus II. Oleh karena itu, penelitian ini berakhir pada siklus II. Berdasarkan hasil penelitian dan analisis data disimpulkan bahwa keterampilan mahasiswa PGSD FKIP Univeristas Sriwijaya dalam membuat media pembelajaran IPS SD berbasis edutainment telah mengalami peningkatan.
\end{abstract}

\section{Kata kunci: Keterampilan Media Pembelajaran, IPS SD, Edutainment}

\section{PENDAHULUAN}

Pendidikan Guru Sekolah Dasar (PGSD) bernaung dalam Fakultas Keguruan dan Ilmu Pendidikan (FKIP) Universitas Sriwijaya. Sebagai salah satu Lembaga Pendidikan Tenaga Keguruan (LPTK), PGSD FKIP Unsri menghasilkan Sarjana Pendidikan yang selanjutnya menjadi Guru Profesional setelah melalui Pendidikan Profesi Guru (PPG). Sebagaimana visi PGSD FKIP Unsri, yaitu menjadi lembaga pendidikan yang terkemuka pada tahun 2025 dalam menghasilkan sarjana pendidikan guru SD yang berakhlak mulia, berkualitas, proaktif dalam pengembangan IPTEK, inovatif dalam pembelajaran serta mampu bersaing di tingkat global. Visi tersebut dapat diwujudkan melalui rincian misi yang ada.

Mahasiswa PGSD FKIP Unsri yang dipersiapkan menjadi Sarjana Pendidikan dengan ilmu ke-SD-an tentu harus memiliki keterampilan yang memadai. Baik dalam soft skils maupun hard skills. Selain itu, juga terdapat keterampilan dasar mengajar. Di antaranya keterampilan bertanya, mengadakan variasi memberi penguatan, mengelola kelas, membuka dan menutup pelajaran. Sebagaimana Usman (2007:74) mengemukakan bahwa terdapat 8 keterampilan dasar mengajar.

Keterampilan-keterampilan tersebut juga bersinergi dengan keterampilan dalam Ilmu Pengetahuan Sosial (IPS). Pembelajaran IPS sebagai salah satu konten di jenjang sekolah dasar tidak terlihat dalam aspek disiplin ilmu. Sapriya (2009:20) mengemukakan hal itu dikarenakan pembelajaran IPS lebih dipentingkan pada dimensi pedagogik dan psikologis serta karakteristik, sehingga kemampuan berpikir peserta didik bersifat holistik. Keterampilan yang dianggap bersinergi tersebut adalah keterampilan bertanya. IPS memerlukan ketiga dimensi tersebut untuk membentuk kemampuan berpikir holistic, sehingga menuntut guru untuk mampu memberikan 
pertanyaan. Baik pertanyaan dasar, maupun pertanyaan lanjut.

Keterampilan lain yang menjadi hal mendasar dan harus dimiliki guru adalah keterampilan mengadakan variasi. Mahasiswa PGSD FKIP Unsri juga dipersiapkan memiliki keterampilan tersebut. Media pembelajaran yang dibuat guru dapat menjadi salah satu indikasi bahwa guru telah mengadakan variasi. Berbagai macam media pembelajaran yang ada akan membuat guru lebih memilih-milih sesuai dengan tujuan pembelajaran. Selanjutnya, guru melakukan variasi atas pemilihan media pembelajaran tersebut.

Sebagaimana Rudy Bretz (dikutip Sumiati \& Azra, 2008:128) mengklasifikasi media menurut ciri utama media menjadi tiga unsur, yaitu suara, visual, dan gerak. Selanjutnya, klasifikasi tersebut dikembangkan menjadi tujuh kelompok, yaitu: a). Media audio-visual-gerak; merupakan media paling lengkap karena menggunakan kemampuan audio-visual dan gerak, b). Media audiovisualdiam; memiliki kemampuan audio-visual tanpa kemampuan gerak, c). Media audio-semi-gerak; menampilkan suara dengan disertai gerakan titik secara linear dan tidak dapat menampilkan gambar nyata secara utuh, d). Media visualgerak; memiliki kemampuan visual dan gerakan tanpa disertai suara, e). Media visualdiam; memiliki kemampuan menyampaikan informasi secara visual tetapi tidak menampilkan suara maupun gerak, f). Media audio; media yang hanya memanipulasi kemampuan mengeluarkan suara saja, g). Media cetak; media yang hanya mampu menampilkan informasi berupa huruf-huruf dan simbol-simbol verbal tertentu saja.

Media pembelajaran berbasis edutainment, tentu saja menggunakan konsep dasar edutainment yang menggunakan unsur hiburan di dalam suatu pembelajaran. Landasan konsep edutainment terdiri dari 3 asumsi. Sebagaimana Hamruni (2013:6) mengemukakan 3 asumsi tersebut, yaitu (1) perasaan positif (senang/gembira) akan mempercepat pembelajaran, sedangkan perasaan negatif, seperti sedih, takut, terancam, dan merasa tidak mampu akan memperlambat belajar atau bahkan bisa menghentikannya sama sekali; (2) jika seseorang mampu menggunakan potensi nalar dan emosinya secara jitu, maka ia akan membuat loncatan prestasi yang tidak terduga sebelumnya; (3) apabila setiap pembelajar dapat dimotivasi dengan tepat dan diajar dengan cara yang benar, cara yang menghargai gaya belajar dan modalitas mereka, maka mereka semua akan mencapai hasil belajar yang optimal.

Berdasarkan kelebihan media berbasis edutainment, maka Mahasiswa PGSD FKIP Unsri dinilai perlu memiliki keterampilan pembuatan media pembelajaran tersebut. Secara khusus, diperlukan juga dalam pembelajaran IPS SD. Beberapa mata kuliah di PGSD FKIP Unsri telah memuat pembahasan konten media pembelajaran, sehingga mahasiswa telah memiliki pengetahuan dan membuat media pembelajaran tersebut dan mengaplikasikan dalam peer teaching. Demikian pula dengan media pembelajaran berbasis edutainment. Sehingga, peningkatan keterampilan mahasiwa atas pembuatan media pembelajaran tersebut perlu dioptimalkan. Tindakan selanjutnya, respons mahasiswa PGSD FKIP Unsri terhadap media pembelajaran IPS SD berbasis edutainment pun dapat dianalisis. Berdasarkan uraian tersebut, artikel ini diberi judul "Peningkatan Keterampilan Mahasiswa PGSD FKIP Universitas Sriwijaya dalam Membuat Media Pembelajaran IPS SD Berbasis Edutainment".

\section{METODE PENELITIAN}

Jenis penelitian yang digunakan dalam pembelajaran keterampilan membuat media IPS SD berbasis edutainment adalah PTK. Mulyasa (2013:11) menyatakan bahwa PTK merupakan suatu upaya untuk mencermati kegiatan belajar sekelompok siswa dengan memberikan sebuah tindakan (treatment) yang sengaja dimunculkan. Tindakan tersebut dilakukan oleh Pendidik, Pendidik bersamasama dengan Peserta Didik, atau oleh Peserta Didik di bawah bimbingan dan arahan Pendidik. Hal itu dimaksudkan untuk memperbaiki dan meningkatkan kualitas pembelajaran.

Subjek penelitian tindakan kelas ini adalah seluruh peserta didik mata kuliah Pembelajaran IPS II, yaitu Mahasiswa PGSD FKIP Universitas Sriwijaya Angkatan 2016 Kelas Inderalaya. Jumlah subjek penelitian ini adalah sebanyak 38 Mahasiswa. Jumlah tersebut terdiri dari 34 Mahasiswi dan 3 Mahasiswa.

Penelitian tindakan kelas ini dilaksanakan pada Mahasiswa PGSD FKIP Universitas Sriwijaya Angkatan 2016 Kelas Inderalaya. PGSD FKIP Universitas Sriwijaya 
Kelas Inderalaya beralamatkan di Jalan Raya Palembang-Inderalaya KM 32 Ogan Ilir.

Penelitian ini dilaksanakan pada tahun ajaran 2017/2018 semester genap. Penentuan waktu penelitian mengacu pada kalender akademik FKIP Universitas Sriwijaya, karena PTK memerlukan beberapa siklus yang membutuhkan proses belajar mengajar yang efektif di kelas.

Pada dasarnya penelitian tindakan ini dilakukan secara bersiklus yang tiap siklusnya terdiri atas empat tahap yaitu perencanaan, pelaksanaan tindakan, observasi, dan refleksi. Perencanaan merupakan langkah pertama dalam setiap kegiatan, tanpa perencanaan, kegiatan yang dilakukan tidak mungkin berjalan dengan baik atau terarah. Melakukan tindakan/pelaksanaan merupakan realisasi dari rencana yang dibuat yang berupa kegiatan belajar mengajar. Tindakan/pelaksanaan pembelajaran ini perlu adanya pengamatan agar dapat ditentukan apakah ada hal-hal yang perlu diperbaiki agar tindakan/pelaksanaan dapat mencapai tujuan yang diinginkan. Setelah pengamatan dilakukan selama proses pembelajaran berlangsung, maka hasil pengamatan tersebut didiskusikan untuk mendapatkan refleksi. Refleksi dilakukan dengan cara merenungkan kembali proses tindakan/pelaksanaan pembelajaran baik mengenai kekurangannya maupun keberhasilannya. Dengan demikian akan dapat

Tabel 1 Kriteria Tingkat Keberhasilan Belajar Peserta Didik dalam \%

\begin{tabular}{cc}
\hline Tingkat Keberhasilan & Keterangan \\
\hline $\mathbf{2 8 0 \%}$ & Sangat tinggi \\
$\mathbf{6 6 - 7 9 \%}$ & Tinggi \\
$\mathbf{4 0 - 5 9 \%}$ & Sedang \\
$\mathbf{2 0 - 3 9 \%}$ & Rendah \\
$\mathbf{2 \mathbf { 2 0 } \%}$ & Sangat rendah
\end{tabular}

\begin{tabular}{llrl}
\multicolumn{2}{c}{ Berdasarkan tabel, } & tingkat & mengukur keterampilan mahasiswa PGSD \\
keberhasilan belajar peserta didik & FKIP Universitas Sriwijaya Angkatan 2016 \\
dikelompokan ke dalam 5 tingkat. Masing- & Kelas Inderalaya membuat media \\
masing persentase tingkat, yaitu $\geq 80 \%, 66-$ & pembelajaran berbasis edutainment. Indikator \\
$79 \%, 40-59 \%, 20-39 \%$, dan $<20 \%$. Secara & keberhasilan dalam penelitian ini adalah hasil \\
berturut-turut, keterangan masing-masing & observasi keterampilan mahasiswa membuat \\
tingkat tersebut adalah sangat tinggi, tinggi, & media pembelajaran berbasis edutainment \\
sedang, rendah, dan sangat rendah. & yang dilakukan pada suatu siklus. Jika pada \\
Instrumen yang digunakan dalam & siklus pertama menunjukan klasikal \\
penelitian ini adalah lembar pedoman & mahasiswa sudah dapat membuat media \\
observasi. Lembar tersebut digunakan untuk & pembelajaran berbasis edutainment, maka
\end{tabular}


siklus kedua tidak perlu dilaksanakan. Namun jika siklus pertama belum mencapai kriteria minimal keterampilan mahasiswa membuat media pembelajaran berbasis edutainment, maka perlu diadakan siklus kedua begitu juga seterusnya.

\section{HASIL \& PEMBAHASAN}

Penelitian ini dilakukan pada

Mahasiswa PGSD FKIP Universitas Sriwijaya Angkatan 2016 Kelas Inderalaya. Penelitian ini dilaksanakan pada tahun ajaran 2017/2018 semester genap. Hal itu mengingat mata kuliah yang digunakan dalam penelitian ini dilaksanakan pada Semester Genap. Mata kuliah yang dimaksud adalah Pembelajaran IPS Kelas Tinggi SD. Penelitian tindakan ini dilaksanakan dalam 2 kali siklus yang sudah dianggap mampu memenuhi kepuasan peneliti dalam mencapai hasil yang diinginkan dan mengatasi persoalan yang ada. Hasil penelitian ini merupakan pendeskripsian data kegiatan pra tindakan, hasil tindakan siklus pertama dan kedua.

Sebelum dilakukan tindakan, peneliti memperoleh data awal dari hasil pembelajaran mahasiswa pada mata kuliah sebelumnya pada Semester Ganjil. Mata kuliah yang dimaksud adalah Pembelajaran IPS Kelas Rendah. Mata kuliah tersebut dilanjutkan pada Semester Genap dengan nama mata kuliah berbeda, yaitu Pembelajaran IPS Kelas Tinggi.

Dalam mata kuliah Pembelajaran IPS Kelas Rendah, mahasiswa sudah mempelajari media pembelajaran. Namun, baru mengenai hakikat media pembelajaran secara umum. Sedangkan, media pembelajaran berbasis edutainment dibelajarkan pada mata kuliah Pembelajaran IPS Kelas Tinggi. Pengetahuan dasar mahasiswa mengenai hakikat media pembelajaran secara umum sudah dapat dikatakan memadai. Hal itu dilihat dari nilai yang diperoleh mahasiswa dari mata kuliah terdahulu, yaitu Pembelajaran IPS Kelas Rendah. Semua mahasiswa telah lulus mata kuliah tersebut. Sehingga, dapat melanjutkan pada mata kuliah Pembelajaran IPS Kelas Tinggi.
Pelaksanaan penelitian pada siklus I telah dilakukan selama tiga kali tindakan. Dalam siklus 1 dapat diuraikan beberapa hal mengenai kegiatan perencanaan, pelaksanaan, pengamatan, dan refleksi. Pada tahapan perencanaan diawali dengan mendiskusikan langkah-langkah tindakan yang dilakukan di siklus 1. Perencanaan tersebut dilakukan sebagai acuan dalam melaksanakan tindakan pada siklus 1. Selain itu, direncanakan juga bentuk evaluasi untuk siklus 1. Sehingga, format evaluasi dan lembar pedoman observasi serta kuesioner telah dirancang pada tahap perencanaan siklus 1. Perencanaan yang dilakukan juga mengacu pada Satuan Acara Perkuliahan (SAP) Mata Kuliah Pembelajaran IPS Kelas Tinggi.

Tindakan pada siklus I dilakukan sebanyak tiga kali. Hal tersebut mengingat keterbatasan penelitian ini. Tindakan pertama berkaitan dengan konten mengenai hakikat media pembelajaran berbasis edutainment, tindakan kedua dan ketiga berkaitan pembuatan media pembelajaran berbasis edutainment. Kegiatan-kegiatan yang dilakukan dalam masing-masing tindakan tersebut mencerminkan proses pembelajaran mahasiswa dalam membuat media pembelajaran berbasis edutainment. Selanjutnya, dilakukan pengamatan terhadap hasil media pembelajaran yang dibuat mahasiswa.

Pengamatan dilaksanakan secara langsung bersamaan dengan pelaksanaan tindakan. Pengamatan dilakukan oleh peneliti secara bersama-sama dengan menggunakan lembar pedoman pengamatan yang telah dibuat pada tahap perencanaan. Pengamatan difokuskan pada tindakan kedua dan ketiga, yaitu saat mahasiswa membuat media pembelajaran berbasis edutainment. Aspekaspek yang diamati, yaitu terdapatnya prinsip hiburan dalam media, perbandingan unsur education dan entertainment, variasi desain media pembelajaran IPS SD berbasis edutainment, content IPS SD dalam media, dan kesesuaian dengan tujuan pembelajaran.

Hasil perhitungan aspek-aspek penilaian keterampilan membuat media pembelajaran IPS SD berbasis edutainment 
pada siklus I dapat dilihat pada tabel di bawah ini.

Tabel 1 Nilai Rata-rata Aspek Penilaian Keterampilan Membuat Media Pembelajaran IPS SD Berbasis Edutainment pada Siklus I

\begin{tabular}{clc}
\hline No & \multicolumn{1}{c}{ Aspek } & Nilai Rata-rata \\
\hline $\mathbf{1}$ & Terdapatnya prinsip hiburan dalam media & 85.90 \\
$\mathbf{2}$ & Perbandingan unsur education dan entertainment. & 59.62 \\
$\mathbf{3}$ & Variasi desain media pembelajaran IPS SD berbasis edutainment & 61.54 \\
$\mathbf{4}$ & Content IPS SD dalam media & 87.18 \\
$\mathbf{5}$ & Kesesuaian dengan tujuan pembelajaran & 74.36 \\
\hline
\end{tabular}

Berdasarkan tabel di atas, terlihat bahwa nilai rata-rata aspek pertama pada siklus I adalah sebesar 85.90. Selanjutnya, nilai rata-rata aspek kedua yang berupa perbandingan unsur education dan entertainment adalah sebesar 59.62. Aspek ketiga, yaitu variasi desain media pembelajaran IPS SD berbasis edutainment memiliki nilai rata-rata sebesar 61.54. Sedangkan, nilai rata-rata aspek keempat yang berupa content IPS SD dalam media adalah 87.18. Aspek terakhir ataupun aspek kelima, yaitu kesesuaian dengan tujuan pembelajaran memiliki nilai rata-rata 74.36. Selain itu, diperoleh nilai rata-rata keterampilan mahasiswa PGSD FKIP Universitas Sriwijaya dalam membuat media pembelajaran IPS SD berbasis edutainment, yaitu sebesar 73.72 .

Berdasarkan tindakan yang dilakukan pada siklus pertama ini tampak bahwa mahasiswa telah membuat media pembelajaran berbasis edutainment. Namun, media pembelajaran berbasis edutainment yang dibuat masih belum memadai dalam fungsi sebagai media pembelajaran. Berdasarkan kelima aspek yang dijadikan indikator pembuatan media pembelajaran berbasis edutainment, baru 2 aspek yang berada pada kategori sangat baik. Kedua aspek yang dimaksud adalah aspek "terdapatnya prinsip hiburan dalam media" dan aspek "content IPS SD dalam media". Ketiga aspek lainnya masih perlu dilakukan pembenahan, yaitu perbandingan unsur education dan entertainment, variasi desain media pembelajaran IPS SD berbasis edutainment, dan kesesuaian dengan tujuan pembelajaran. Sehingga, hasil tersebut menunjukan bahwa perlu dilaksanakan siklus II.

Pelaksanaan penelitian pada siklus II telah dilakukan selama tiga kali tindakan.
Dalam siklus II dapat diuraikan beberapa hal mengenai kegiatan perencanaan, pelaksanaan, pengamatan, dan refleksi. Pada tahapan perencanaan diawali dengan mendiskusikan langkah-langkah tindakan yang dilakukan di siklus II. Perencanaan tersebut dilakukan sebagai acuan dalam melaksanakan tindakan pada siklus II. Selain itu, direncanakan juga bentuk evaluasi untuk siklus II. Sehingga, format evaluasi dan lembar pedoman observasi telah dirancang pada tahap perencanaan siklus II.

Tindakan pada siklus II juga dilakukan sebanyak tiga kali. Hal tersebut mengingat keterbatasan penelitian ini. Tindakan pertama berkaitan dengan konten mengenai kriteria media pembelajaran berbasis edutainment, tindakan kedua dan ketiga berkaitan pembuatan media pembelajaran berbasis edutainment. Kegiatan-kegiatan yang dilakukan dalam masing-masing tindakan tersebut mencerminkan proses pembelajaran mahasiswa dalam membuat media pembelajaran berbasis edutainment. Selanjutnya, dilakukan pengamatan terhadap hasil mediap pembelajaran yang dibuat mahasiswa pada siklus II.

Pengamatan dilaksanakan secara langsung bersamaan dengan pelaksanaan tindakan. Pengamatan dilakukan oleh peneliti secara bersama-sama dengan menggunakan lembar pedoman pengamatan yang telah dibuat pada tahap perencanaan. Pengamatan difokuskan pada tindakan kedua dan ketiga, yaitu saat mahasiswa membuat media pembelajaran berbasis edutainment. Aspekaspek yang diamati, yaitu terdapatnya prinsip hiburan dalam media, perbandingan unsur education dan entertainment, variasi desain media pembelajaran IPS SD berbasis 
edutainment, content IPS SD dalam media, dan kesesuaian dengan tujuan pembelajaran.

Aspek-aspek yang menjadi kekurangan pada siklus I menjadi pusat perhatian dalam proses pengamatan pada siklus II. Aspek-aspek yang telah terpenuhi dan yang belum terpenuhi pada siklus I, menjadi terpenuhi atau terdapat perubahan juga pada siklus II. Hal itu menunjukan bahwa tindakan yang dilakukan pada siklus II memberi efek. Efektivitas tersebut dapat dikatakan baik ataupun tidak baik dengan melihat hasil perhitungan yang telah dilakukan. Hasil perhitungan aspek-aspek penilaian keterampilan membuat media pembelajaran IPS SD berbasis edutainment pada siklus II dapat dilihat pada tabel di bawah ini.

Tabel 2 Nilai Rata-rata Aspek Penilaian Keterampilan Membuat Media Pembelajaran IPS SD Berbasis Edutainment pada Siklus II

\begin{tabular}{clc}
\hline No & \multicolumn{1}{c}{ Aspek } & Nilai Rata-rata \\
\hline $\mathbf{1}$ & Terdapatnya prinsip hiburan dalam media & 92.95 \\
$\mathbf{2}$ & Perbandingan unsur education dan entertainment. & 87.18 \\
$\mathbf{3}$ & Variasi desain media pembelajaran IPS SD berbasis edutainment & 86.54 \\
$\mathbf{4}$ & Content IPS SD dalam media & 95.59 \\
$\mathbf{5}$ & Kesesuaian dengan tujuan pembelajaran & 84.62 \\
\hline
\end{tabular}

Berdasarkan tabel di atas, terlihat bahwa nilai rata-rata aspek pertama pada siklus I adalah sebesar 92.95. Selanjutnya, nilai rata-rata aspek kedua yang berupa perbandingan unsur education dan entertainment adalah sebesar 87.18. Aspek ketiga, yaitu variasi desain media pembelajaran IPS SD berbasis edutainment memiliki nilai rata-rata sebesar 86.54 . Sedangkan, nilai rata-rata aspek keempat yang berupa content IPS SD dalam media adalah
95.59. Aspek terakhir ataupun aspek kelima, yaitu kesesuaian dengan tujuan pembelajaran memiliki nilai rata-rata 84.62. Selain itu, diperoleh nilai rata-rata keterampilan mahasiswa PGSD FKIP Universitas Sriwijaya dalam membuat media pembelajaran IPS SD berbasis edutainment, yaitu sebesar 88.97.

Perbedaan nilai rata-rata dari masingmasing aspek pada siklus I dan siklus II dapat digambarkan pada diagram batang berikut ini.

Gambar 1 Diagram Nilai Rata-rata Keterampilan Membuat Media Pembelajaran IPS SD Berbasis Edutainment Siklus I dan Siklus II

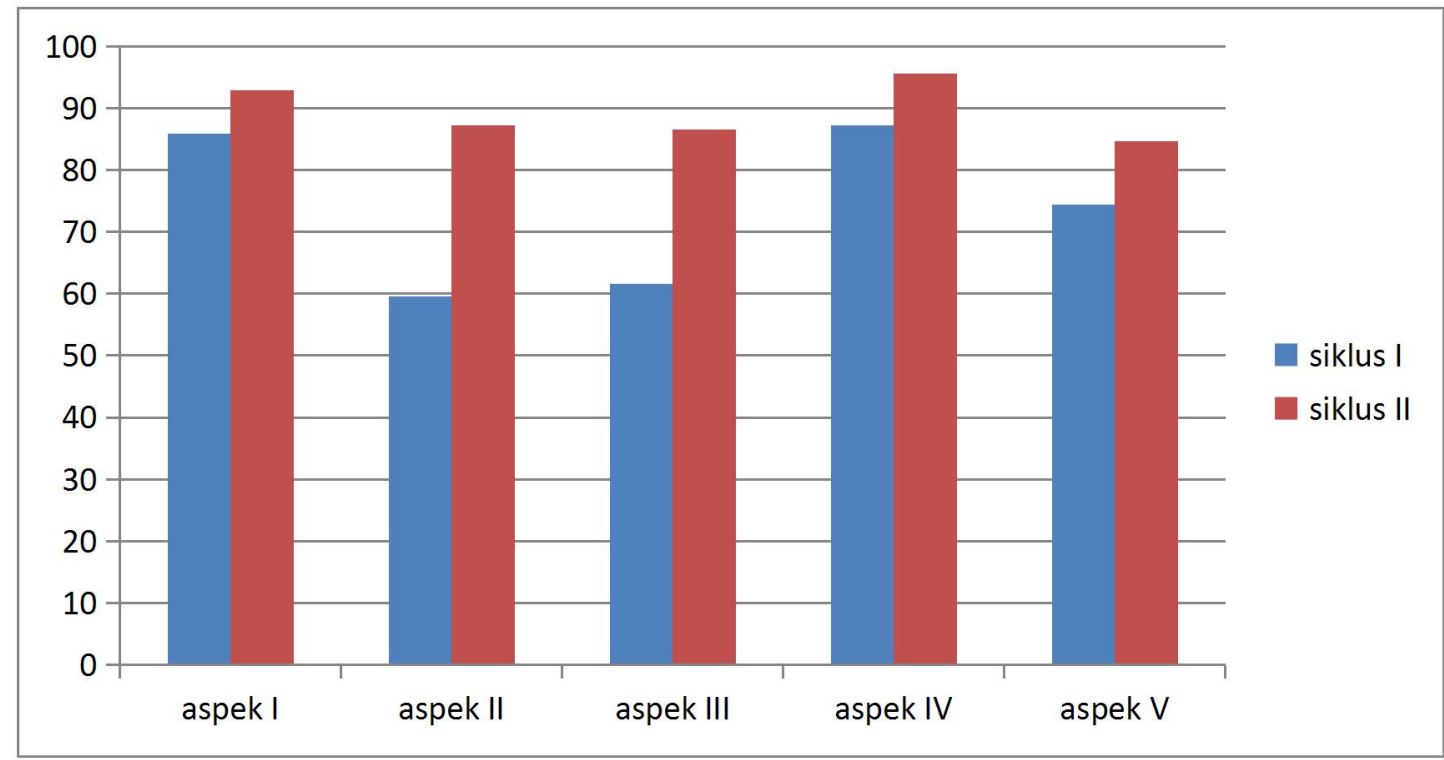

Berdasarkan diagram di atas, terlihat bahwa terdapat perubahan nilai rata-rata keterampilan membuat media pembelajaran IPS SD berbasis edutainment siklus I dan siklus II. Dengan kata lain, diagram tersebut menunjukan bahwa nilai rata-rata keterampilan membuat media pembelajaran IPS SD berbasis edutainment pada siklus I dan siklus II tidak sama. Nilai rata-rata keterampilan membuat media pembelajaran IPS SD berbasis edutainment antara siklus I dan siklus II mengalami peningkatan. 
Setelah dilakukan pengamatan pada siklus II, semua aspek yang dijadikan indikator pembuatan media pembelajaran berbasis edutainment telah dapat dilakukan guna menghasilkan suatu media pembelajaran berbasis edutainment yang layak digunakan sesuai dengan aspek penilaian kinerja yang telah ditentukan. Prinsip hiburan dalam media pembelajaran berbasis edutainment telah dipenuhi mahasiswa dengan melibatkan permainan di dalam media pembelajaran yang dibuat. Perbandingan unsur education dan entertainment telah dianalisis, sehingga tidak menjadi lebih banyak unsur education ataupun unsur entertainment. Kesesuaian dengan tujuan pembelajaran atas media pembelajaran yang dibuat mahasiswa dapat diukur dari indikator pembelajaran. Selanjutnya, indikator tersebut telah dicantumkan dalam media pembelajaran berbasis edutainment yang telah dibuat mahasiswa.

Oleh karena semua aspek yang
dijadikan indikator pembuatan media pembelajaran berbasis edutainment telah dipenuhi guna menghasilkan suatu media pembelajaran yang layak, maka peneliti memutuskan untuk tidak melanjutkan penelitian ini pada siklus selanjutnya. Hal ini sesuai dengan indikator keberhasilan dalam penelitian sebagaimana yang telah diuraikan dalam metode penelitian ini.

Keterampilan membuat media pembelajaran berbasis edutainment menjadi sangat diperlukan. Hal itu dikarenakan media pembelajaran berbasis edutainment memiliki banyak kegunaan. Sebagaimana Susanto (2014:331) menyatakan bahwa penggunaan media pembelajaran berbasis edutainment dapat membangkitkan keinginan dan minat yang baru, serta rangsangan kegiatan belajar, bahkan membawa pengaruh-pengaruh psikologis terhadap peserta didik. Melalui unsur hiburan yang ada, media pembelajaran berbasis edutainment diharapkan akan lebih disukai peserta didik dibandingkan dengan pembelajaran biasa.

Keterampilan membuat media pembelajaran juga menjadi salah satu wujud inovasi yang dilakukan guru, sehingga menjadi hal yang sangat diperlukan. Inovasi tersebut juga dapat mengatasi permasalahan di kelas yang nantinya akan ditemui calon guru SD. Permasalahan yang dimaksud antara lain pembelajaran yang kurang menarik. Sebagaimana Mardani dkk (2013) yang menyatakan bahwa pembelajaran yang kurang menarik dan mengakibatkan tujuan pembelajaran yang belum tercapai, dapat diatasi dengan melakukan inovasi melalui pembuatan media pembelajaran.

Konsep edutainment sendiri yang menggabungkan education dan entertainment. Artinya, menggabungkan pendidikan dan hiburan. Konsep tersebut membuat siswa dapat belajar sambil bermain. Sehingga, guru dianggap perlu untuk memiliki keterampilan membuat media pembelajaran berbasis edutainment. Sebagaimana pendapat Suyanto (2005:119-121) yang mengemukakan bahwa bermain memiliki peran penting dalam perkembangan peserta didik pada hampir semua bidang perkembangan, baik motorik, kognitif, afektif, bahasa maupun sosial.

KESIMPULAN \& SARAN Berdasarkan hasil penelitian dan analisis data dapat ditarik kesimpulan bahwa keterampilan mahasiswa PGSD FKIP Universitas Sriwijaya Angkatan 2016 dalam membuat media pembelajaran IPS SD berbasis edutainment telah mengalami peningkatan. Hal itu terlihat dari diagram dan tabel yang telah disajikan pada hasil penelitian. Mahasiswa PGSD FKIP Universitas Sriwijaya Angkatan 2016 sudah pernah membuat media pembelajaran. Hal itu dikarenakan beberapa mata kuliah lain telah mensyaratkan mahasiswa dapat membuat media pembelajaran. Namun, media pembelajaran berbasis edutainment baru mulai dibuat mahasiswa ketika mengukuti mata kuliah Pembelajaran IPS Kelas Tinggi.

Mahasiswa terlebih dahulu memiliki pengetahuan dasar mengenai media pembelajaran berbasis edutainment. Oleh karena itu, konsep mengenai media pembelajaran berbasis edutainment dibahas dalam diskus. Selanjutnya, mahasiswa baru 
membuat media pembelajaran berbasis edutainment. Hasil kinerja mahasiswa dalam membuat media pembelajaran berbasis edutainment diukur dengan menggunakan lembar penilaian kinerja yang menjadi dasar kelanjutan siklus dalam penelitian ini.

Pada siklus I, keterampilan mahasiswa PGSD FKIP Universitas Sriwijaya Angkatan 2016 dalam membuat media pembelajaran IPS SD berbasis edutainment masih perlu dikembangkan. Hal itu ditunjukan dari masih terdapat aspek-aspek yang belum berada pada kategori baik. Berdasarkan kelima aspek yang dijadikan indikator pembuatan media pembelajaran berbasis edutainment, baru 2 aspek yang berada pada kategori sangat baik. Kedua aspek yang dimaksud adalah aspek "terdapatnya prinsip hiburan dalam media" dan aspek "content IPS SD dalam media". Ketiga aspek lainnya masih perlu dilakukan pembenahan, yaitu perbandingan unsur education dan entertainment, variasi desain media pembelajaran IPS SD berbasis edutainment, dan kesesuaian dengan tujuan pembelajaran.

Pada siklus II, keterampilan mahasiswa PGSD FKIP Universitas Sriwijaya Angkatan 2016 dalam membuat media pembelajaran IPS SD berbasis edutainment sudah mengalami peningkatan. Hal itu ditunjukan dari telah terpenuhinya setiap aspek penilaian kinerja. Prinsip hiburan dalam media pembelajaran berbasis edutainment telah dipenuhi mahasiswa dengan melibatkan permainan di dalam media pembelajaran yang dibuat. Perbandingan unsur education dan entertainment telah dianalisis, sehingga tidak menjadi lebih banyak unsur education ataupun unsur entertainment. Kesesuaian dengan tujuan pembelajaran atas media pembelajaran yang dibuat mahasiswa dapat diukur dari indikator pembelajaran. Selanjutnya, indikator tersebut telah dicantumkan dalam media pembelajaran berbasis edutainment yang telah dibuat mahasiswa.

Berdasarkan hasil yang diperoleh dalam penelitian ini maka disarankan kepada mahasiswa agar memperhatikan perbandingan unsur edukasi dan hiburan dalam pembuatan media pembelajaran berbasis edutainment. Apabila hal itu tidak diperhatikan, maka akan dapat membuat siswa yang menggunakan media tersebut menjadi terlena. Artinya, siswa menjadi fokus pada hiburan saja dan tujuan pembelajaran menjadi tidak tercapai.

DAFTAR PUSTAKA

Arikunto, Suharsimi, dkk. 2010. Penelitian Tindakan Kelas. Jakarta: Bumi Aksara.

Arsyad, A. 2011. Media Pembelajaran. Jakarta: PT Raja Grafindo Persada.

Aqib, Zainal dkk. 2010. Penelitian Tindakan Kelas. Bandung: Yrama Widya.

BSNP. 2006. Standar Isi Untuk Satuan Pendidikan Dasar dan Menengah.Standar Kompetensi dan Kompetensi Dasar SD/MI. Jakarta:BSNP.

Budiarjo, Lily. 2007. Keterampilan Belajar. Yogyakarta: Penerbit Andi

Fadlillah, M. 2014. Edutainment Pendidikan Anak Usia Dini. Jakarta: Kencana.

Goleman, Daniel. 1996. Emotional Intelligence Why it Can Matter More Than IQ, Bantam Books, New York.

Hamruni. 2013. Pembelajaran Berbasis Edutainment. Yogyakarta: FITK UIN Sunan Kalijaga.

Hasanah, Nurul Usrotun. 2015. Peran Media dalam Pembelajaran. https://www.kompasiana.com/nurulusro tunhasanah/55595fad6523bd0c74c0726 4/peran-media-dalam-pembelajaran (diakses tanggal 13 Oktober 2018).

Mardani dkk. 2013. Pembuatan Media Pembelajaran Interaktif Keterampilan Komputer Dan Pengelolaan Informasi Untuk Sekolah Menengah Kejuruan Kelas XI. Indonesian Jurnal on Computer Science - Speed - IJCSS Volume 10 No 4 - November 2013 ijcss.unsa.ac.id

Mitasari, Nur Rizka. 2018. "Model Pembelajaran Edutainment dalam Perkembangan Kognitif Siswa Sekolah Dasar". Jurnal Cakrawala Pendas Vol. 4 No. 1 Edisi Juli 2018

Mulyasa, H.E. 2013. Praktik Penelitian Tindakan Kelas. Bandung: Remaja Rosdakarya.

Nurgiyantoro, Burhan. 2010. Penilaian Pembelajaran Bahasa Berbasis Kompetensi. Yogyakarta: BPFEYOGYAKARTA. 
Rohani, A. 1997. Media Instruksional Edukatif. Jakarta: PT. Rineka Cipta.

Sadiman, Arief S., Rahardjo, R., Haryono, Anung., \& Rahardjito. 2012. Media Pendidikan:

Pengertian, Pengembangan, dan Pemanfaatannya. Jakarta: Rajawali Press.

Sapriya. 2009. Pendidikan IPS. Bandung: Remaja Rosdakarya.

Sudijono, Anas. 2009. Pengantar Evaluasi Pendidikan. Jakarta: Rajagrafindo Persada.

Sudjana, Nana. 2013. Penilaian Hasil Proses Belajar Mengajar. Bandung: Remaja Rosdakarya.

Sukiman. 2012. Pengembangan Media Pembelajaran. Yogyakarta: Pedagogia.

Sumiati \& Arza. 2008. Metode Pembelajaran. Bandung: Wacana Prima.

Surya, Mohammad. 1992. Psikologi Pendidikan Cetakan Ke 5 (Revisi). Bandung: Jurusan PPB FIP UPI.

Susanto, A. 2014. Pengembangan Pembelajaran IPS di Sekolah Dasar. Jakarta: Prenadamedia Group.

Sutrisno. 2005. Revolusi Pendidikan di Indonesia : Membedah Metode dan Teknik Pendidikan Berbasis Kompetensi. Yogyakarta: Ar-Ruzz.

Suyanto, Slamet, Dasar-dasar Pendidikan Anak Usia Dini. Yogyakarta: Hikayat Publishing.

Taneo, S. P., \& Angin, Ignasius Suban. 2008. Kajian IPS SD. Jakarta:Dirjen Dikti Depdiknas.

Tedjasaputra, Mayke S. 2001. Bermain, Mainan, dan Permainan : Untuk Pendidikan Usia Dini. Jakarta: Grasindo.

Trianto. 2011. Model Pembelajaran Terpadu Konsep, Strategi, dan Implementasinya dalam Kurikulum Tingkat Satuan Pendidikan (KTSP). Jakarta:Bumi Aksara.

Usman, M.U. 2007. Menjadi Guru Profesional. Bandung: Remaja Rosdakarya. 